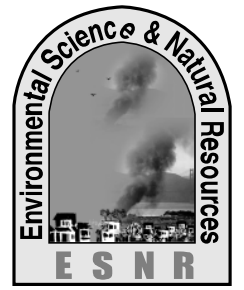

J. Environ. Sci. \& Natural Resources, 5(2): 53 -57, 2012

ISSN 1999-7361

\title{
Assessment of Some Water Quality Parameters of Bansi River in Monsoon and Winter Seasons
}

\author{
M. M. M. Hoque, S. Roy, M. N. Hoque and M. Z. Islam
}

Abstract

Department of Environmental Science and Resource Management, Mawlana Bhashani Science and Technology University, Santosh, Tangail-1902, Bangladesh

\begin{abstract}
The study was carried out to assess some physico-chemical water quality parameters and pollution scenario of the Bansi river. Water samples were collected from 8 different selected stations at Bagholpur to Nayarhat portion of Bansi river during winter and monsoon periods. The values of all parameters except temperature and DO were found higher in winter season compared to that of monsoon season. The water was slightly alkaline to strongly alkaline ranging from average $\mathrm{pH}$ value of 7.6 in monsoon to 8.5 in winter. The DO was found unsuitable for fisheries and irrigation purposes. The BOD was found extremely higher in winter than that of standard level set by the Government of Bangladesh. The mean values of EC in monsoon was $452.4 \mu \mathrm{s} / \mathrm{cm}$, whereas in winter season it was $901 \mu \mathrm{S} / \mathrm{cm}$, the value of DO in monsoon season was $4.7 \mathrm{mg} / \mathrm{l}$ whereas in winter it was $3.2 \mathrm{mg} / \mathrm{l}$, the value of BOD in monsoon season was $8.9 \mathrm{mg} / \mathrm{l}$ and in winter season it was $31.4 \mathrm{mg} / \mathrm{l}$, the value of TDS in monsoon season was 306.3 $\mathrm{mg} / \mathrm{l}$ and in winter season it was $496 \mathrm{mg} / \mathrm{l}$, the value of alkalinity in monsoon season $50.4 \mathrm{mg} / \mathrm{l}$ and in winter season it was 146.5 $\mathrm{mg} / \mathrm{l}$.
\end{abstract}

Key words: Bansi river, Monsoon, Pollution, Water quality parameters and Winter Season

\section{Introduction}

Bangladesh, a land of rivers, has about 700 rivers including tributaries (Chowdhury, 2001). Water is the most valuable and vital resource for sustenance of life and also for any kinds of developmental activity (Kumar et al., 2010). There are generally three types of water source - surface water, rain water and ground water sources. In Bangladesh rainfall and transboundary river flows are the main sources of surface water. Two main rivers, the Ganges and the Brahmaputra account for more than $80 \%$ of stream flows. Currently, pollution has become a major threat to the existence of mankind on this earth (Trivedi, 1992). Water pollution is a visible form of environmental pollution. Rivers are choked with industrial effluents and untreated sewage through numerous outfalls (Khan, 1999). Land use activities such as urbanization and agriculture severely affect water quality and aquatic habitats of rivers, streams, lakes and estuaries (Ayers and Westcot, 2000). Bansi river is one of the polluted river in Dhaka division. Different kinds of industries are found closely connected alongside the Bansi river. Many kinds of business have been flourished beside the river. A great portion of bank of the Bansi river is occupied by business related activities (Nahar, 2000). Physical properties such as color, odor and temperature, and chemical properties such as $\mathrm{pH}$, electrical conductivity, dissolved oxygen, biological oxygen demand and total dissolved solids are important quality parameters of water. Any abnormalities in their properties indicate deterioration of water quality. A very few study is available on water quality of Bansi river. The study intends mainly to investigate several water quality parameters of the Bansi river in two seasons and the present level of pollution river water.

\section{Materials and Methods}

Water samples were collected from eight different locations along Bansi river in monsoon and winter seasons and analyzed the $\mathrm{pH}, \mathrm{EC}$, temperature, TDS, DO, BOD and alkalinity. Water samples were collected in triplicates from each location. The $\mathrm{pH}$ and temperature were determined immediately in the field and EC, TDS, DO, BOD and alkalinity were measured in the laboratory.

\section{Sampling Sites}

The Bansi river is located within $23^{\circ} 93^{\prime}$ to $23^{\circ} 81^{\prime}$ north latitude and $90^{\circ} 21^{\prime}$ to $90^{\circ} 26^{\prime}$ east longitude. The water samples were collected from eight stations along Bansi river. The selected sampling sites were Baghalpur, Namabazar, Baktarpur, Jamsingh, Teuti, Ghugudia, Gokulnagar, Nayarhat. The location of the study area is shown in Fig. 1.

\section{Sample collection}

Water samples were collected from different stations in monsoon and winter seasons. Samples were collected in plastic bottles and their openings are closed properly. After sampling the bottles were screwed and marked with the respective identification number.

\section{Sample analysis}

The $\mathrm{pH}$ was determined by digital $\mathrm{pH}$ meter (HANNA Instrument 211, Microprocessor $\mathrm{pH}$ ). Total dissolved solids and electrical conductivity were determined by 
digital TDS meter and EC meter (HM digital). Temperature was determined by Thermometer. Dissolved oxygen was determined by Winkler's Iodometric method, and Biological oxygen demand
(BOD) and alkalinity were determined by titrimetric method as described by Huq and Alam (2005). Alkalinity is measured and reported in terms of $\mathrm{CaCO}_{3}$ equivalent.

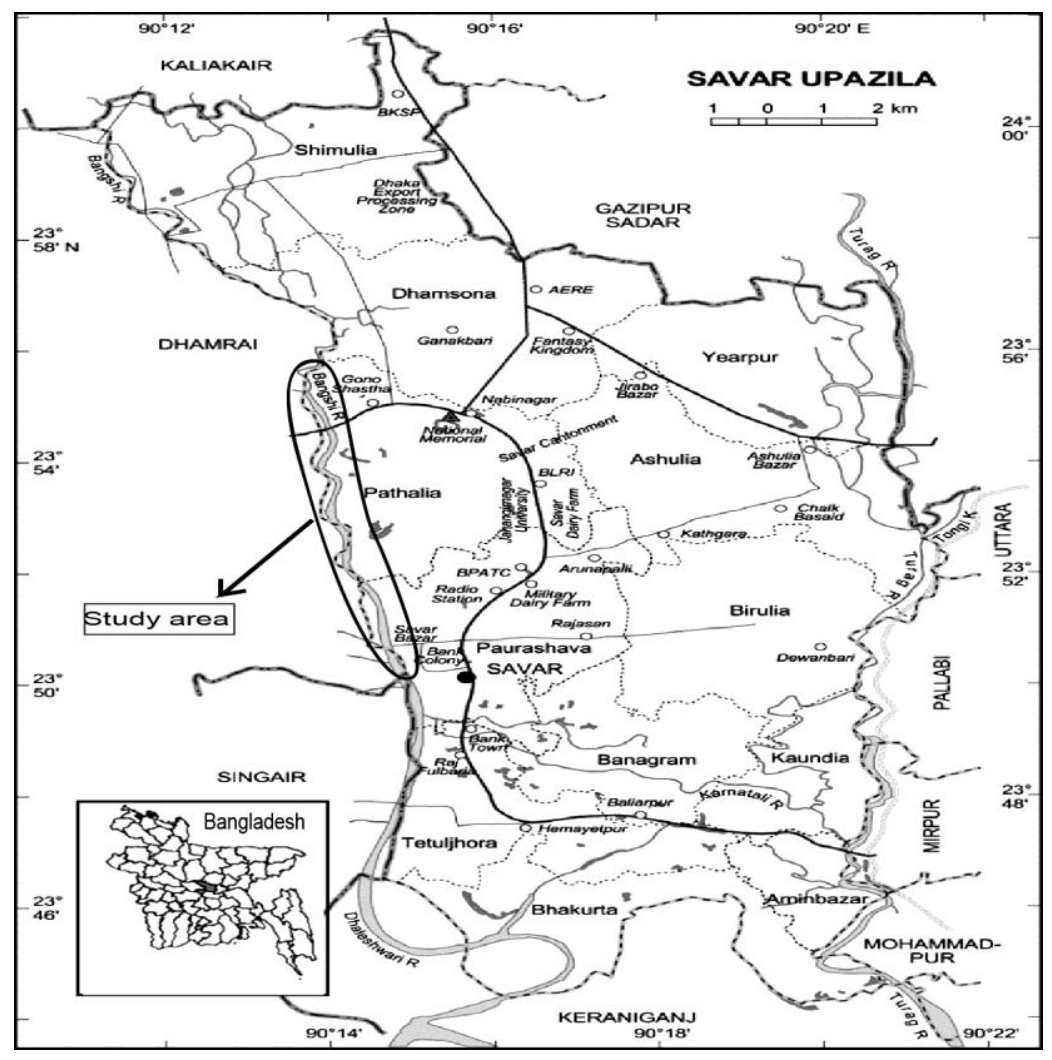

Fig. 1. Map showing the location of study area.

\section{Results and Discussion}

The water quality of the river was assessed by analyses of some particular parameters and compared with different standards.

\section{Physico-chemical properties of water}

\section{Color and Odor}

Color and odor of water of the river were observed visually. The observed color was light brown in wet season and deep black in dry season. Color in water is due to the presence of humic or fulvic acids, metallic ions and colored industrial wastes. Pure water has no color (Gupta, 2001). Bad organic odor was found in some places in winter season.

\section{pH}

The $\mathrm{pH}$ values of different station in monsoon and winter season are shown in Table 1 and 2. Among different stations, the highest value was observed at
Teuti and lowest at Baktarpur in monsoon, whereas in winter season, the highest value was observed at Baghalpur and lowest at Ghugudia. The average $\mathrm{pH}$ value of water in monsoon period was 7.61 and in winter 8.5. The standard value of surface water ranges from 6.5-8.5 (ECR, 1997). Ahmed \& Rahman (2000) reported that in most raw water sources $\mathrm{pH}$ lies in the range of 6.5- 8.5. The $\mathrm{pH}$ of the study area was slightly alkaline to strongly alkaline that is unsuitable for aquatic life.

\section{Temperature}

Table 1 and 2 shows the temperature at different stations in monsoon and winter. Among different stations, in monsoon, the highest temperature was observed at Nayarhat $\left(29.5^{\circ} \mathrm{C}\right)$ and lowest at Ghugudia $\left(29.5^{\circ} \mathrm{C}\right)$, whereas in winter season, the highest value was observed at Ghugudia $\left(23.2^{\circ} \mathrm{C}\right)$ and lowest at Namabazar $\left(19.3^{\circ} \mathrm{C}\right)$ station. The fluctuation in river water usually depends on the season, geographic location, sampling time and temperature 
of effluents entering the stream (Ahipathy \& Puttaiah, 2006). The standard value of temperature of river water is $20^{\circ} \mathrm{C}-30^{\circ} \mathrm{C}(\mathrm{ECR}, 1997)$. The average temperature was found $30.9^{\circ} \mathrm{C}$ in monsoon season and $21.5^{\circ} \mathrm{C}$ in winter season.

Table 1. Water quality parameters of Bansi river in monsoon season

\begin{tabular}{|l|l|c|c|c|c|c|c|c|}
\hline No. & $\begin{array}{l}\text { Name of the } \\
\text { Stations }\end{array}$ & $\mathrm{pH}$ & $\begin{array}{c}\mathrm{EC} \\
(\mu \mathrm{S} / \mathrm{cm})\end{array}$ & $\begin{array}{c}\text { TDS } \\
(\mathrm{mg} / \mathrm{l})\end{array}$ & $\begin{array}{c}\text { Temp. } \\
\left({ }^{\circ} \mathrm{C}\right)\end{array}$ & $\begin{array}{c}\text { DO } \\
(\mathrm{mg} / \mathrm{l})\end{array}$ & $\begin{array}{c}\text { BOD } \\
(\mathrm{mg} / \mathrm{l})\end{array}$ & $\begin{array}{c}\text { Alkalinity } \\
(\mathrm{mg} / \mathrm{l})\end{array}$ \\
\hline 1 & Baghalpur & 7.6 & 432 & 292 & 30.8 & 4.7 & 9.3 & 46.0 \\
\hline 2 & Namabazar & 7.6 & 475 & 313 & 31.2 & 4.8 & 9.7 & 48.7 \\
\hline 3 & Baktarpur & 7.5 & 448 & 310 & 30.7 & 4.7 & 9.3 & 51.7 \\
\hline 4 & Jamsingh & 7.7 & 448 & 297 & 30.3 & 4.5 & 8.2 & 54.0 \\
\hline 5 & Teuti & 7.8 & 437 & 301 & 31.4 & 4.8 & 7.8 & 54.7 \\
\hline 6 & Ghugudia & 7.5 & 461 & 312 & 29.5 & 5.2 & 7.8 & 53.7 \\
\hline 7 & Gokulnagar & 7.7 & 457 & 313 & 31.4 & 4.9 & 9.2 & 46.0 \\
\hline 8 & Nayarhat & 7.6 & 461 & 312 & 31.5 & 4.2 & 9.6 & 48.3 \\
\hline
\end{tabular}

\section{Electrical Conductivity (EC)}

Electrical conductivity usually used for indicating the total concentration of ionized constituents of water (Huq \& Alam, 2005). The standard value of electrical conductivity is $300 \mu \mathrm{S} / \mathrm{cm}$ (De, 2007). The highest EC $(908 \mu \mathrm{S} / \mathrm{cm})$ in dry season was found at Baktarpur and in monsoon, the highest EC (475 $\mu \mathrm{S} / \mathrm{cm}$ ) was found at Nayarhat station. The values of EC at different stations are shown in Table 1 and 2. The average value of EC in monsoon season was $452.4 \mu \mathrm{S} / \mathrm{cm}$ and in winter season, it was $901 \mu \mathrm{s} / \mathrm{cm}$. These values exceeded the standard value which indicates the pollution of Bansi river.

\section{Total Dissolved Solids (TDS)}

The values of TDS at different stations are shown in Table 1 and 2. The highest TDS in winter season was found at Ghugudia (528 mg/l), and lowest was found at Nayarhat station $(467 \mathrm{mg} / \mathrm{l})$. In monsoon season, the highest TDS was found in Gokulnagar and Namabazar stations $(313 \mathrm{mg} / \mathrm{l})$ and lowest at Baghalpur station $(292 \mathrm{mg} / \mathrm{l})$. Both in winter and monsoon the values of TDS of most locations were found within permissible limit of $500 \mathrm{mg} / \mathrm{l}$ for drinking purpose (Huq \& Alam, 2005). These indicate that the water at some locations of Bansi river is not suitable for drinking purposes but it can be used for aquatic and irrigation purposes in respect of TDS.

Table 2. Water quality parameters of Bansi River in winter season

\begin{tabular}{|l|l|c|c|c|c|c|c|c|}
\hline No. & $\begin{array}{l}\text { Name of the } \\
\text { stations }\end{array}$ & $\mathrm{pH}$ & $\begin{array}{c}\mathrm{EC} \\
(\mu \mathrm{S} / \mathrm{cm})\end{array}$ & $\begin{array}{c}\mathrm{TDS} \\
(\mathrm{mg} / \mathrm{l})\end{array}$ & $\begin{array}{c}\text { Tem. } \\
\left({ }^{\circ} \mathrm{C}\right)\end{array}$ & $\begin{array}{c}\text { DO } \\
(\mathrm{mg} / \mathrm{l})\end{array}$ & $\begin{array}{c}\text { BOD } \\
(\mathrm{mg} / \mathrm{l})\end{array}$ & $\begin{array}{c}\text { Alkalinity } \\
(\mathrm{mg} / \mathrm{l})\end{array}$ \\
\hline 1 & Baghalpur & 8.8 & 898 & 495 & 21.1 & 2.5 & 28.0 & 142.3 \\
\hline 2 & Namabazar & 8.6 & 902 & 488 & 19.3 & 1.9 & 31.7 & 144.3 \\
\hline 3 & Baktarpur & 8.7 & 908 & 504 & 21.7 & 3.7 & 30.3 & 148.0 \\
\hline 4 & Jamsingh & 8.3 & 904 & 499 & 21.4 & 3.4 & 26.8 & 155.0 \\
\hline 5 & Teuti & 8.5 & 894 & 504 & 22.9 & 3.6 & 26.3 & 146.3 \\
\hline 6 & Ghugudia & 8.0 & 897 & 528 & 23.2 & 5.2 & 31.2 & 146.0 \\
\hline 7 & Gokulnagar & 8.7 & 903 & 488 & 20.7 & 2.8 & 36.7 & 143.7 \\
\hline 8 & Nayarhat & 8.6 & 902 & 467 & 21.5 & 2.4 & 39.8 & 146.3 \\
\hline
\end{tabular}




\section{Dissolve Oxygen (DO)}

Dissolved oxygen is a vitally important parameter of water that is required for aquatic organisms. In natural and waste water, DO levels depend on the physical, chemical and biological activities in the water body (Huq \& Alam, 2005). Dissolved oxygen levels below $1.0 \mathrm{mg} / \mathrm{l}$ will not support fish; levels of 5 to $6 \mathrm{mg} / \mathrm{l}$ are usually required for most of the aquatic organisms. Both in monsoon and winter seasons, the highest value of DO $(5.2 \mathrm{mg} / \mathrm{l})$ was found at Ghugudia. The average DO value in monsoon was found $4.7 \mathrm{mg} / \mathrm{l}$ and in winter it was $3.2 \mathrm{mg} / \mathrm{l}$. The values of DO of different stations showed in Table 1 and 2. The optimum value of DO for good water quality is 4-6 mg/l. In all the stations except Ghugudia, DO values were found less than 4 $\mathrm{mg} / \mathrm{l}$ in winter season. The lower DO values in the study area indicate higher microbial load and pollution of the river water.

\section{Biological Oxygen Demand (BOD)}

The average value of BOD in monsoon season was $8.9 \mathrm{mg} / \mathrm{l}$ and in winter season, it was $31.4 \mathrm{mg} / \mathrm{l}$. The highest value of BOD $(9.7 \mathrm{mg} / \mathrm{l})$ was observed at Namabazar station in monsoon and in winter season, the highest value $(39.8 \mathrm{mg} / \mathrm{l})$ was observed at Nayarhat station (Table 1 and 2). More the oxidizable organic matter present in water, more the BOD (Gupta, 2001). The biodegradation of organic materials exerts oxygen tension in the water and increases the biological oxygen demand (Abida and Harikrishna, 2008).

\section{Alkalinity}

Generally water alkalinity is caused by basic species like bicarbonate ion, carbonate ion and hydroxide ion. Alkalinity of Bansi river water was higher in winter season than the monsoon. The highest alkalinity in monsoon was found at Teuti station $(54.7 \mathrm{mg} / \mathrm{l})$ and lowest values were found at Baghalpur and Gokulnagar stations $(46 \mathrm{mg} / \mathrm{l})$. In winter season, the highest value was found at Jamsingh $(155 \mathrm{mg} / \mathrm{l})$ and lowest value was found at Baghalpur station (142.3 $\mathrm{mg} / \mathrm{l})$.

The $\mathrm{pH}$ values of Bansi river water were higher in winter and lower in monsoon season. Like $\mathrm{pH}$, the EC and TDS values were also found higher in winter than monsoon. In contrast, the values of temperature were found higher in monsoon compared to winter. Similarly, the values of DO were found higher in monsoon and lower in winter. On the contrary, the BOD values were found higher in winter and lower in monsoon. Similar to BOD, alkalinity values of all stations were found higher in winter than monsoon.
The lower levels of $\mathrm{pH}, \mathrm{EC}$, TDS, BOD and alkalinity during monsoon are due to dilution of river water by rain water as well as runoff. In a study conducted by Ahmad et al. (2010), high concentration of heavy metals was found during dry season compared to pre-monsoon and monsoon. In another study, the mean values conductivity was found 84 $\mu \mathrm{S} / \mathrm{cm}$ in monsoon whereas $805 \mu \mathrm{S} / \mathrm{cm}$ in dry season; DO was $5.52 \mathrm{mg} / \mathrm{l}$ in dry season and $5.72 \mathrm{mg} / \mathrm{l}$ in monsoon; BOD was $1 \mathrm{mg} / \mathrm{l}$ in dry season and 0.878 $\mathrm{mg} / \mathrm{l}$ in monsoon, and total solid was $149.4 \mathrm{mg} / \mathrm{l}$ in dry season and $145.7 \mathrm{mg} / \mathrm{l}$ in monsoon (Alam et al., 2010).

\section{Conclusion}

The values of all the water quality parameters were found higher in winter except temperature and DO. Some of the parameters were higher than the recommended value, which suggest that the Bansi river to a certain extent is polluted and the water is not completely safe for aquatic organisms, irrigation and other purposes. The causes of pollution should be determined and a proper planning for development and management of the river should be taken to control the pollution of the water of Bansi river.

\section{References}

Abida, B. and Harikrishna. 2008. Study on the Quality of Water in Some Streams of Cauvery River. E-Journal of Chemistry, 5 (2): 377-384

Ahipathi, M. V. and Puttaiah, E. T. 2006. Ecological Characteristics of Vrishabhavathi River in Bangalore (India). Environmental Geology, 49: 1217-1222.

Ahmed, M. F. and Rahman, M. M. 2000. Water Supply and Sanitation. ITN-Bangladesh, Centre for Water Supply and Waste Management, BUET, Dhaka, Bangladesh.

Ahmad, M. K.; Islam, S; Rahman, S.; Haque, M. R. and Islam, M. M. 2010. Heavy Metals in Water, Sediment and Some Fishes of Buriganga River, Bangladesh. Int. J. Environ. Res., 4(2): 321-332.

Alam, M. J. B.; Islam, M. R., Muyen, Z.; Mamun, M. and Islam, S. 2007. Water Quality Parameters along Rivers. Int. J. Environ. Sci. Tech., 4 (1): 159-167. 
Ayers, R. S. and Westcot, D.W. 2000. Water Quality for Agriculture. FAO Irrigation and Drainage Paper 29.

Chowdhury, Q. M. 2001. Water and Environment, Forum of Environmental Journalist of Bangladesh, ISBN- 983-756-004-8.

De, A. K. 2007. Environmental Chemistry. New age international limited. New Delhi.

ECR. 1997. The Environment Conservation Rules. Government of the People's Republic of Bangladesh. Ministry of Environment and Forest. pp. 205-207.

Huq S. M. I. and Alam, M. D. 2005. A Handbook on Analysis of Soil, Plant and Water. BACERDU, Univerversity of Dhaka, Bangladesh. pp. xxii-246.

Gupta, P. K. 2001. Methods in Environmental Analysis: Water, Soil and Air. Agrobios Publication. India.
Khan, H. R. 1999. Irrigation Water Pricing in Bangladesh. In: Proceedings of the expert group meeting on water pricing. United Nations Water Resources Series no. 55, pp. 5566 .

Kumar, G. N. P.; Srinivas, P.; Chandra, K.G. and Sujatha, P. 2010. Delineation of groundwater potential zones using Remote sensing and GIS techniques: A Case Study of Kurmapalli Vagu Basin in Andhra Pradesh, India. International Journal of Water Resources and Environmental Engineering, 2(3):70-78.

Nahar, S. 2000. Water Quality of the Buriganga River and Its Environmental Situation. Unpublished M.Sc. Report. Department of Geography and Environment. Jahangirnagar University, Savar. Dhaka.

Trivedi, R. N. 1992. Environmental Problems Prospects and Constrains. Armol Publications. India. 